\title{
Phytosanitary Practices And Evaluation Of 17 Pesticides Residues In Tomatoes Fruits Produced In Foumbot District Western Highland-Cameroon
}

\author{
Sopkoutie NGK \\ Abdulai AN \\ Tarla DN \\ Djeugap FJ
}

Plant pathology and agricultural zoology research unit (UR-PHYZA), Faculty of Agronomy and Agricultural Sciences (FASA), University of

Dschang,Cameroon

Galani YJH

School of Food Science and Nutrition, University of Leeds, Leeds,UK

\section{Ekengoue CM}

African Scientific Association for Innovative and Entrepreneurship (ASAIE), Dschang, Cameroon

\section{Tabang WM}

Nya $E$

National Laboratory of Analysis and Diagnosis of Plant Products and Inputs (LNAD),Messa Yaoundé, Cameroon

\section{Payne VK}

Department of Animal Biology, Faculty of Science, University of Dschang

Doi:10.19044/esj.2021.v17n3p30

Submitted: 07 November 2020

Accepted: 11 January 2021

Published: 31 January 2021
Copyright 2021 Author(s)

Under Creative Commons BY-NC-ND

4.0 OPEN ACCESS

Cite As:

Sopkoutie NGK., Abdulai AN., Tarla DN., Galani YJH., Djeugap FJ., Ekengoue CM., Tabang WM., Nya E. \& Payne VK. (2021). Phytosanitary practices and evaluation of 17 pesticides residues in tomatoes fruits produced in Foumbot district Western Highland-Cameroon. European Scientific Journal, ESJ, 17(3), 30.

https://doi.org/10.19044/esj.2021.v17n3p30

\section{Abstract}

The involvement of pesticides in agriculture requires the implementation of best phytosanitary practices in order to guarantee the health of populations and preserve the environment. This study focused on the assessment of phytosanitary practices of tomato producers in Foumbot, 
Western Highlands-Cameroon, and evaluated the residues of 17 pesticides in tomatoes. The methodological approach consisted of field investigations by survey, collection of samples, pesticide residue extraction using QuEChERS method, and their analysis by gas chromatography tandem mass spectrometry (GC-MS). Survey of 100 farmers showed that, they did not comply with the instructions for the use of plant protection products: 56\% of farmers interviewed increased the dose of products when they noticed its ineffectiveness; 93\% did not the respect pre-harvest intervals; while 77\% increased the application frequency at the time of fruiting. All the producers work without personal protective equipment (PPE) and 68\% of them use empty packaging for packaging consumable including water, red oil and palm wine. The reuse of empty packaging could expose populations (producers and consumers) to numerous health risks. Regarding pesticides residues, 03 actives ingredients were detected and quantified in the samples, all the samples were contaminated by lambda-cyhalothrin, $86.66 \%$ by cypermethrin and $66.66 \%$ by acetamiprid. Moreover, residue concentrations above the maximum residue limit (MRL) were found in all the positive samples of lambda-cyhalothrin, and $92.30 \%$ of cypermethrin positive samples. This study shows that utilization of plant protection products in Foumbot requires extensive monitoring with producers, in order to reduce risk of consumers exposure.

Keywords: Pesticide Residues, Phytosanitary Practices, Maximum Residue Limit, Gas Chromatography, Quechers, Cameroon

\section{Introduction}

In Cameroon, the cultivation of tomato (Lycopersicon esculentum Mill.) employs around 329,000 producers and is carried out in all agro-ecological zones of the country, both in peri-urban and rural areas, and in all seasons (FAO, 2018). It is cultivated on 93,762 hectares on average with a production less than 583,177 tones (FAOSTAT, 2018). This cultivation is mainly practiced by small-scale farmers and represents an important source of income; about $83 \%$ of the production is intended for sale (MINADER, 2012; FAO, 2018). The average daily tomato consumption for adults is $31.7 \mathrm{~g} /$ day (Ingenbleek et al., 2017). Tomato is one of the most important crops in terms of income in the horticultural sector in Cameroon, as in other countries of the Central African sub-region. Across the country, tomato cultivation is intensifying with production rates between $62 \%$ in the West, $28 \%$ in the Center, $7 \%$ in the North-West and 3\% for the other regions of Cameroon (FAO, 2018). However, tomato cultivation in Cameroon faces numerous constraints, especially the pressure of insects pests (Chougourou et al., 2012) and diseases (Camara et al., 2013). In order to maintain or even increase the 
level of agricultural and horticultural production, but also to ensure the supply of quality foodstuffs meeting quality criteria, producers generally use plant protection products commonly called pesticides (Tarla, 2015; AGRESTE, 2016). Pesticides are used by farmers in Cameroon for plant protection not only during the production stage, but also during post-harvest storage of produces (Galani et al., 2018).

Being a Solanaceous plant and prone to various diseases, the tomato plant is cultivated under an intense spray regime of various phytosanitary products (Tarla et al., 2015). Although the modes of action and the methods of application of these phytosanitary products are constantly improving, the use of pesticides for protecting crops also almost inevitably leads to the presence of residues, which unfortunately can harm the health of farmers, consumers and the quality of the environment (Kpan Kpan et al., 2019; Bazzi, 2012). Reports show that several factors, which can contribute to high consumer exposure, such as intensive use due to poor level of understanding, related to pesticide use are encountered in Cameroon. This is a consequence of insufficient training on plant protection products, and limited assistance from agricultural extension agents, resulting in an inappropriate use of pesticides, documented in several studies carried out in different parts of the country (Kenko et al., 2017; Manfo et al., 2019; Tandi et al., 2014; Tarla et al., 2015; Tayoh et al., 2016). Moreover, large amounts of obsolete stocks accumulated over the years in the country (Tarla, 2014), coupled with the weak control of the stockpile of obsolete pesticides by Government agencies. These obsolete pesticides can be sources of acute and chronic illnesses (Gimou et al., 2008). Some of these products are even sold and used fraudulently (Kenko et al., 2017; Sonchieu et al., 2017). As result, residues of persistent organic pollutants which have been banned such as DDT, lindane, alachlor, aldrin, heptachlor and their metabolites, have been found in food products from Cameroon (Galani et al., 2018; Sonchieu et al., 2010). In addition, Cameroonian cocoa, representing a major export crop, has been refused on the European market due to their contamination by metalaxyl residues beyond the limit value $(0.1 \mathrm{mg} / \mathrm{kg})$ as indicated by the European Union (EU). These results have prompted the Cameroonian government to prohibit importation, marketing and use of all pesticides made from metalaxyl (MINADER, 2016). In addition, a study in Nkol'Ossananga in the Centre Region of Cameroon revealed that crude petroleum derivatives and gasoline used by farmers as additives to phytosanitary products are major sources of environmental pollution (EKengoue et al., 2018).

The latest studies dating back to 12 years have shown a low rate of population exposure to pesticide residues in the Yaoundé, and the author recommended carrying out an investigation using more sensitive analytical methods (Gimou et al., 2008). Recently it has been shown that corn (Zea 
mays), millet (Pennisetum glaucum) and sorghum (Sorghum bicolor) from northern Cameroon contained residues above the maximum residue limit (MRL) (Sonchieu et al., 2013 and Sonchieu et al., 2010). In addition, an evaluation of pesticide residues in 12 agricultural products from the highlands of west Cameroon showed that most of the foods contained at least one pesticide, and 21 pesticides (34.4\% of the tested compounds) exceeded their EU MRL (Galani et al., 2018). Recently, report (Galani et al., 2020) on the monitoring and dietary risk of 81 pesticides residues in 11 local agricultural products from 3 majors towns of Cameroon, showed that 58 compounds were detected in the samples, more than half of the positive samples had residue content above the EU MRLs and 5 pesticides of them, are banned in the country. Pesticide application by tomato producers in Foumbot was shown to be inappropriate, and analysis of pesticide residues in the tomato fruits from this area was recommended by (Tarla et al., 2015). It appears that improper practices of pesticide usage may lead to high residue levels in the environment and in agricultural products but little is known about the situation of tomatoes from Foumbot, one of the highest tomato-producing areas in the country. Therefore, this study aimed to assess the phytosanitary practices of tomato producers in Foumbot and determine the level of pesticide residues in tomatoes from this area.

\section{Materials and Methods Description of study area}

Foumbot is a town in the West Region in the Western Highlands of Cameroon located $25 \mathrm{~km}$ from the regional capital of Bafoussam and $48 \mathrm{~km}$ from the nearest tourist town of Foumban. Geographically, Foumbot is in the southern half of the Noun alluvial plain between latitudes $5^{\circ} 16^{\prime}$ and $5^{\circ} 35^{\prime} \mathrm{N}$ then longitudes $10^{\circ} 30^{\prime}$ and $10^{\circ} 45^{\prime} \mathrm{E}$ (Figure 1). The climate is tropical Sudano-Guinean characterized by two seasons: a long rainy season (midMarch to mid-November) and a short dry season (mid-November to midMarch). The average rainfall varies between 2,500 and 5,000 $\mathrm{mm}$ of precipitation per year. The soils are mostly of volcanic origin and essentially consist of tropical ferruginous soils with little leaching and black with a high agronomic value given their richness in nitrogen, phosphorus and potassium. Regarding the hydrography of the locality, the main limit on the west side of the town is materialized by the Noun River, Foumbot's main hydrographic resource. Small streams of lesser importance also exist and are complemented by the Nkoup river which crosses a large part of the town longitudinally. 


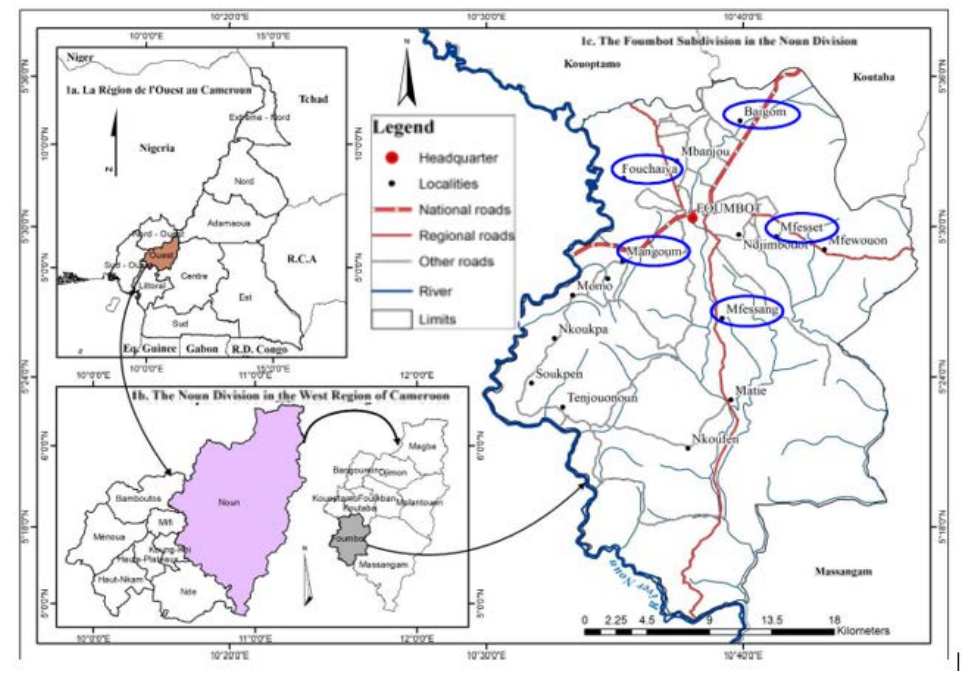

Figure 1. Location of the study area

\section{Identification of farmers in the study area}

In order to identify the study area, databases from the local office of the Cameroon Ministry of Agriculture and Rural Development (MINADER) were used. The database was well-established, identifying all agricultural groups in the subdivision. These groups are classified according to the main crops cultivated. Using this database, all the farmers who participated in tomato production were sorted and classified according to the different villages in the sub-division. Out of the many villages that make up the Foumbot Sub-division, five were found to have a greater proportion of farmers involved in tomato production. These include Baigom, Mfessang, Fouchaiya, Mfesset, Mangoum.

\section{Survey questionnaire}

A well-developed questionnaire containing both closed multiplechoice and open-ended questions, was established to collect important information on tomato cultivation from the growers. The data allowed us to assess the phytosanitary practices of tomato growers by having a clear idea on demographic social characteristics (sex, level of education, age, and matrimonial status), agronomic practices (cropping season and cropping system), application of pesticides (source of information's relating to the use of pesticides, the moment of application, reaction following the ineffectiveness of the product, respect pre-harvest intervals, knowledge of the presence of residues in the fruits, the fate of the remaining mixtures, maximum application stage, wearing of PPE and disposal of empty packaging).

An individual semi-structured survey was carried out in February 2020. Twenty randomly selected tomato producers were interviewed face-to-face in 
each village. Each interview lasted between 15 to 20 minutes depending on the collaboration of the interviewed farmers. In each farm, the owner was targeted first, and if the latter was not available, an employee was interviewed.

\section{Collection of samples and analysis of pesticide residues}

15 (Fifteen) samples of 500 g each, were taken from three producers among respondents from each village in three villages chosen arbitrarily. The equipment used for the harvest of tomatoes had been previously cleaned with water and gloves were worn to avoid any contamination. In addition, rows at the edge of plots $(1.0 \mathrm{~m})$ as well as diseased plants and rotten fruit were excluded for sampling. Samples were individually packaged in aluminum foil and freezer plastic bags, labelled, and transported within $24 \mathrm{~h}$ to the National Laboratory of Analysis and Diagnosis of Plant Products and Inputs (LNAD) of MINADER, in a cooler containing ice cubes and maintained at a temperature of $4^{\circ} \mathrm{C}$. In the laboratory, samples were stored at $-21^{\circ} \mathrm{C}$ in a refrigerator as proposed by (Mahugija, 2017). The extraction and purification were carried out using the QuEChERS AOAC 2007.01 method previously developed by (Steven, 2007), and the analysis was carried out on GC-MS.

\section{Reagents for residue analysis}

QuEChERS AOAC Pouch Qsep sachets containing magnesium sulfate and sodium acetate were procured from Agilent (Santa Clara, USA). HPLC grade acetonitrile was purchased from ROMIL (Cambridge, UK), while glacial acetic acid, PSA (primary and secondary amine), deionized water, acetone, HPLC grade standard solution of pesticides were obtained from sigma Aldrich, Germany

\section{Sample preparation}

Five hundred grams of each sample were grounded in a mill (Retsch GM 200) at a speed of $3500 \mathrm{rpm}$ for $1 \mathrm{~min}$. It was transferred into a $500 \mathrm{ml}$ beaker, and $15 \mathrm{~g}$ of homogenized sample was introduced in a $50 \mathrm{ml}$ centrifuge tube. Subsequently $15 \mathrm{ml}$ of acetonitrile solvent containing $1 \%(\mathrm{v} / \mathrm{v})$ acetic acid and a sachet of Qsep containing $6 \mathrm{~g}$ of anhydrous magnesium sulfate and $1.5 \mathrm{~g}$ of sodium acetate were then introduced into the tube. The tube was vortexed (Iswis Vt) for $1 \mathrm{~min}$, and the mixture was centrifugated for $35 \mathrm{~min}$ at $1500 \mathrm{rpm}$. For cleanup, $8 \mathrm{ml}$ of supernatant was introduced into a $15-\mathrm{ml}$ centrifuge tube, then $1.2 \mathrm{~g}$ of magnesium sulfate and $0.4 \mathrm{~g}$ of PSA were added into the tube. After swirling manually and vortexing for $1 \mathrm{~min}$, the mixture was centrifugated for $35 \mathrm{~min}$ at $1500 \mathrm{rpm}$. One $\mathrm{ml}$ of supernatant was introduced into a $1.5 \mathrm{ml}$ chromatography vial for injection on gas chromatography. 


\section{Gas chromatography tandem Mass Spectrometry}

The apparatus used was an Agilent Technology 7890A gas chromatograph comprising an automatic injector G4513A, an Agilent 5975 C TAD VL MSD mass detector equipped with three detection axes, and an Agilent J\&W GC capillary column of $30 \mathrm{~m}$ length, $0.250 \mathrm{~mm}$ diameter and a film of $0.25 \mu \mathrm{m}$. This equipment was controlled by a microcomputer equipped with The Agilent GC Chemstation Plus version G1701EA E.02.02.1431 software. The injection $(1 \mu \mathrm{l})$ was carried out in spitless mode and helium was used as carrier gas at $1.2 \mathrm{ml} / \mathrm{min}$.

The operating conditions of the GC were as follows: initial temperature of the injector: $150^{\circ} \mathrm{C}$; temperature of the detectors: $310^{\circ} \mathrm{C}$; the column was initially set at a temperature of $70^{\circ} \mathrm{C}$, then increased at a rate of $25^{\circ} \mathrm{C} / \mathrm{min}$ to $280^{\circ} \mathrm{C}$ and held for $5 \mathrm{~min}$

\section{Data analysis}

Descriptive statistics were generated for survey data and for each pesticide. Percentages of farmers, positives samples and samples above the MRL were calculated. The lowest, highest, and median residue contents were computed using Microsoft Excel 2016 software.

\section{Results and discussion}

\section{Sociodemographic characteristics of tomato farmers}

Analysis of the survey showed that the tomato producers were mostly men $(70 \%)$ with women representing only $30 \%$ of producers. A similar result was also obtained by (Tarla et al., 2015) which showed that the studied population consisted of $98.3 \%$ men and only $1.7 \%$ women. A comparison between the results of the two studies shows that there has been a considerable increase in women and a slight decrease in the number of men during the last five years, among the tomato growers in this area. This variation can be considered as the direct consequence of the mass movement of populations from English-speaking Regions to the closest French-speaking areas following the national political crisis resulting in North West and South West (NOSO) of 530,000 internally displaced persons (Petrigh, 2019).

Overall, farmers had a basic level of education at primary (46\%) and secondary (40\%). Only a few farmers attended higher education (6\%). The rest (8\%) had never been to school. A large portion of the farming population includes students but also traders who abandoned their studies and markets, respectively following the NOSO crisis to take refuge in Foumbot. This may explain why the majority (89\%) of producers are made up of young people aged between 20 and 49 years old [20-29 years (24\%), 30-39 years (40\%), 40 49 years (25\%)]. The rest are the elderly including parents (over 50), representing only $11 \%$ of the surveyed population. On the matrimonial level, 
the population consisted mainly of married people (72\%) (Table 1). The low level of education, the lack of training and information added to the social pressure (Cameroonian NOSO crisis) which forces refugees to engage in income-generating activities for their survival are the main causes of the poor phytosanitary practices observed in tomato growers in western Cameroon (Foumbot), as studies by (Ahouangninou et al., 2011), (Son et al., 2017), (Wognin et al., 2013), (Badiane, 2004), (Kanda et al.,2013) and (Gouda et al., 2018). Don't we often say an empty stomach has no ears'? Once a refugee from the crisis manages to gain possession of a portion of arable land, what matters next is the production in quantity in order to increase income and be able to take care of the whole family. Consequently, none of the instructions for using phytosanitary products as indicated by the manufacturers whose doses and frequencies of application are no longer respected. For $94 \%$ of the producers questioned, agriculture is the main or sole activity. These producers are exclusively market gardeners (90\%), although they are not specialized on a single vegetable crop. When a complementary agricultural activity exists, they are producers of corn, sugar cane and egusi. Only $47 \%$ of farmers own the land they operate, the others are linked to a third party owner generally belonging to the same family (farmer or not) obtained by inheritance or having benefited from a family inheritance in order to fight and to meet his needs. However, nearly $95 \%$ of producers surveyed believe that if it is necessary to change their way of producing, this will be in order to maximize their production by making available to them more efficient and inexpensive products in order to fight against all diseases and pest reducing their agricultural yield.

Table 1: Sociodemographic characteristics of tomato farmers in Foumbot, Western highland Cameroon.

\begin{tabular}{|c|c|c|}
\hline & $\begin{array}{c}\text { Social status of } \\
\text { tomato producers }\end{array}$ & $\begin{array}{c}\text { Percentage } \\
\text { (\%) }\end{array}$ \\
\hline Sex & Men & 70 \\
\hline Producer age group & Women & 30 \\
\hline & $20-29$ & 24 \\
\hline & $30-39$ & 40 \\
\hline & $40-49$ & 25 \\
\hline Level of education & $50-59$ & 11 \\
\hline & No & 8 \\
\hline & Primary & 46 \\
\hline & Secondary & 40 \\
\hline
\end{tabular}

$\mathrm{N}=100$ 


\section{Agronomic practices and cropping systems}

According to the survey, $57 \%$ of producers use land areas less than or equal to 1 ha representing individual or family production systems. Areas between 1-5 ha and $>5$ ha, generally belong to community groups. Half (51\%) of the producers preferred to cultivate tomatoes in the dry season more precisely in the lowlands with swamps. Irrigation water was taken from surrounding streams using motor pumps. About $40 \%$ of producers cultivated in both seasons, which requires a fairly large investment for the purchase of inputs in the rainy season and finally to better manage the pest and disease pressure (Fontem, 2003). Only 9\% of producers cultivated tomatoes in the rainy season only, applying phytopharmaceutical products once a week or more. This implies a high cost of plant protection products and the hired labor for an intensive spray regime when the family labor is insufficient. Employees used are paid an average of $\$ 0.33$ per sprayer, $\$ 4.17$ per day and $\$ 50$ per month (Asongwe et al., 2014) depending on the position of their plots located upstream or in non-swampy areas, the most expensive activity was therefore based on pest and disease management. These findings corroborate with the work of Tarla et al., (2015) reporting that for the growing season, more than half of tomato producers (51\%) cultivated in the dry season. This choice is justified by the fact that, during this season, markets are more suitable for tomato selling and the plants are less susceptible to diseases. Some farmers (40\%) have enough funds to allow them to cultivate during both seasons.

Two tomato cultivation systems are used at Foumbot such as monoculture (33\%), and mixed cropping (67\%). Crops associated with tomatoes included peppers (Capsicum spp.), huckleberry (Solanum scabrum), green beans (Phaseolus vulgaris) and leeks (Allium ampeloprasum). This result is in agreement with another study (Tarla et al. 2015) which showed that only $5 \%$ of tomato producers practiced the monoculture, $10 \%$ in combination with maize, $20 \%$ in combination with okra (Abelmoschus caillei) and $27 \%$ in combination with huckleberry. Mixed crops make it possible to diversify income, reduce the pressure of diseases and pests especially when the intercrop is not from the Solanaceae family. Watermelon (Citrullus lanatus), green beans and peppers have a shorter life cycle than tomatoes (around 3 to 4 months). Thus, giving the financial resources necessary for the success of tomato crops, farmers often use the income from the intercrops to be able to pay certain direct costs such as the purchase of inputs and labor.

\section{Phytosanitary practices of producers}

\section{Source of advice for selecting a phytosanitary product}

Among the phytosanitary products used by producers to manage tomato diseases and pests in Foumbot, 59\% are recommended by sellers, 37\% come from advice from neighbors, $4 \%$ tomato buyers. When farmers notice that the 
neighboring farm is in good health, they go there and get information on the phytosanitary product used and repeat the same in their own farm. Sellers only intervene when the producers complain, generally about the ineffectiveness of the products used. Concerning new products, the seller decides on the dose of the product to be used for good field efficiency, instead of the recommended dose by the manufacturer. A quarter (24\%) of growers inquired about the proper use of pesticides from vendors at the time of purchase. Information can also be taken later after purchasing the product, usually when ineffectiveness arises. Only $17 \%$ of producers get information from other farmers, the latter recommending by experience of the effectiveness of the product.

\section{Pesticide compounds used}

According to Cissé et al. (2006), Kanda et al. (2013) and Wognin et al. (2013), the use of pesticides requires a minimum of practical and theoretical knowledge to minimize the adverse effects on human health and the environment. To manage pests and pathogens, producers use different types of synthetic chemical pesticides. The results of the survey showed more than almost four-fifths (79.31\%) are insecticides while only 13.79 and $6.90 \%$ are fungicides and herbicides, respectively. Different concentrations and families of active ingredients are used for disease and pest management (Table 2). Pyrethrynoids and neonicotinoids are the highest groups used in the area, while all farmers use lambda cyhalothrin followed by chlorantraniliprole (98\%), which is a pesticide not registered in Cameroon. Some authors have reported Bemisia tabaci and Helicoverpa amigera resistance to pyrethrynoids in Burkina Faso (Gnakine et al., 2013; Abou et al., 2010).

The moth insect Tuta absoluta locally called "Boko Haram" is the predominant pest of tomato in Foumbot. All the producers surveyed in our study area recognized it as the most dangerous pest during the dry season. Essentially chemical control, is based on the use of chlorantraniliprole $200 \mathrm{~g} / \mathrm{l}$ but the cost is really high. As the cost of the product is high, tomato growers prefer to buy it in retail. On the other hand, application of a mixture made from Cypermethrin at $200 \mathrm{~g} / \mathrm{kg}$ and gasoline have been recorded. However, the initiation of treatment is decided without considering a threshold of harmfulness. Overall, few producers implement techniques allowing to avoid the use of chemical pesticides. The addition of gasoline derived from crude oil, to plant protection products either with a view to improved pesticide efficacy or with a view to minimizing cost also constitutes an enormous danger for the health of the applicator and his environment. Indeed, Ekengoue et al., (2018) in their study on the influence of artisanal sand mining on the health and safety of artisans and the environment in the Nkol'Ossananga quarry in Centre Region of Cameroon, showed that crude oil derivatives such as gasoline, used by tomato growers as additives to Plant protection products 
consist a serious chemical risk. These chemical compounds are polycyclic aromatic hydrocarbons (PAHs), sulfur (S), polychlorinated biphenyls (PCB), tributyltin (TBT), dichlorodiphenyltrichloroethane (DDT), lead (Pb) and cadmium (Cd). These are agents of pollution of the various environments of the ecosystem (Ekengoue et al., 2018). In this study, the authors provided clear explanations on the mode of contamination of terrestrial, aquatic and aerial environments due to the use of products derived from crude oil, of the same chemical composition or even similar, in the artisanal sand mining site of Nkol'Ossananga while building on the work of Payne et al., (1985), Stephens et al., (1981), and Amiotte-Suchet (2013). By citing these authors, Ekengoue et al. (2018) highlight climate change. A consequence of the use of crude oil derivatives used in artisanal sand mining deported to the tomato cultivation activity in Western Highlands of Cameroon. Producers did not leave pesticide mixtures on the farm. Generally, the farmers finished the mixture and returned home both with the pesticide and the backpack sprayer due to security in the area, returning home with the sprayer and pesticides constitute a serious health hazard to the farmer's household especially when the containers have been opened or partially opened. Chronic illnesses and poisonings have been reported in Foumbot and the local population generally attributes them to witchcraft but we can understand the role of pesticide storage as a major factor.

Table 2. The most used active ingredients for growing tomatoes in Foumbot, Western highland Cameroon.

\begin{tabular}{|c|c|c|c|c|}
\hline Pesticides & Families & Active ingredients & $\begin{array}{l}\text { \% of Active } \\
\text { Ingredient in } \\
\text { formulations }\end{array}$ & $\begin{array}{c}\% \\
\text { of } \\
\text { use }\end{array}$ \\
\hline \multirow{13}{*}{$\begin{array}{l}\text { Insecticid } \\
\text { es }\end{array}$} & Antranilic Diamides & chlorantraniliprole & 200 & 98 \\
\hline & Avermectins & emamectin benzoate & $50 ; 10$ & 62 \\
\hline & Oxadiazin & Indoxacarb & 300 & 7 \\
\hline & Pyrethroids & lambda-cyhalothrin & $15 ; 60 ; 40$ & 100 \\
\hline & & Alphamethrin & 180 & 23 \\
\hline & & Cypermethrin & $100 ; 50 ; 20$ & 95 \\
\hline & Avermectins & Abamectin & 18 & \\
\hline & Neonicotinoids & Imidacloprid & $30 ; 40$ & 75 \\
\hline & & Acetamiprid & $20 ; 10$ & 72 \\
\hline & & Thiamethoxam & 30 & 19 \\
\hline & Carbamate & Methomyl & 250 & 80 \\
\hline & Organophosphorus & chlorpyrifos-ethyl & 200 & 87 \\
\hline & Phenylpyrazole & fipronil & 50 & 6 \\
\hline \multirow{2}{*}{$\begin{array}{c}\text { Fungicide } \\
\text { S }\end{array}$} & Carbamates & Mancozeb & 80 & 67 \\
\hline & Dithiocarbamate & Maneb & 80 & 3 \\
\hline \multirow{2}{*}{$\begin{array}{c}\text { Herbicide } \\
\text { s }\end{array}$} & \multirow[t]{2}{*}{ Pyridines } & Glyphosate & $26,45,68$ & 6 \\
\hline & & Paraquat & 20 & 83 \\
\hline
\end{tabular}




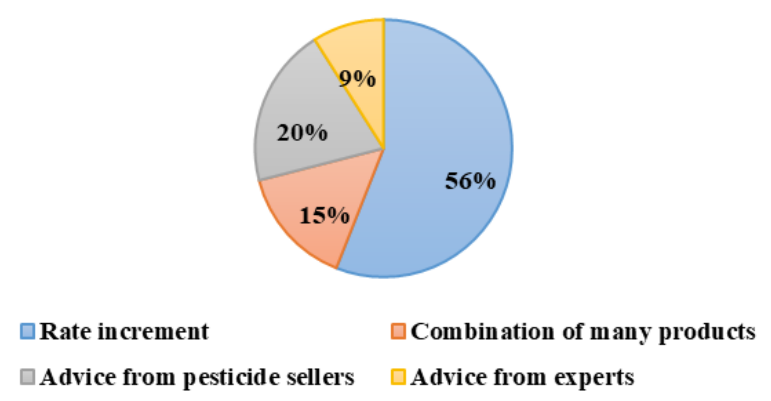

Figure 2. Distribution of tomato producers according to their reactions following ineffective pesticides in their plots

\section{Timing of pesticide application}

Products are applied at various times of the day. Some growers do this at any time of the day, but in the majority of cases, pesticides are sprayed in the morning. In fact, of the 100 producers interviewed, 36\% carry out their treatments in the morning ( 6 to 9 a.m.), 34\% carry them out at any time, 10\% spray in the afternoon (1 to 4 p.m.) and 20\% in the evening (4 to 6 p.m.).

Naturally, the majority of producers do not respect the time allocated between the last treatment and the harvest. Up to $93 \%$ of producers do not respect or ignore the pre-harvest interval. Of the formulations used, $98 \%$ are essentially liquid and $2 \%$ are powder. The application of plant protection products is accelerated at the time of fruiting: $77 \%$ of farmers affirmed that they increased the treatment as well as the frequencies at the time of fruiting until maturity. A fifth (20) of farmers have stated that they achieve maximum application of the products at flowering and only 3\% say that they maintain the same spray rate throughout the plant cycle. On the other hand, the notion of pesticide residues present in fruits is very surprising for tomato growers: 91\% declared having no idea about the presence of residues of pesticides used for treatment in the fruits. In the study of Sonchieu et al 2019 on Farmers' Knowledge, Attitude and Practices on Pesticide Safety: A Case Study of Vegetable Farmers in Mount-Bamboutos Agricultural Area, Cameroon (12\%) of sprayers did not know the existence of residues after application.

In order to preserve the health of final consumers, it must be ensured that the pesticide residues present in the fruits and vegetables treated do not exceed the MRL (Son et al., 2017). The surveys show us that the producers stop spraying the fruits not according to the manufacturer recommendations, but according to their own perception of the presence of pests and diseases in their plots (especially when the fruits are already present). Several reasons can explain this behavior: (i) wrong timing of treatment, (ii) desire to save on products, (iii) pressure of work. Similar trend was also observed by (Ahouangninou et al., 2011) and (Kanda et al., 2013) although the percentages 
of compliance and non-compliance with acceptable daily intake are different. FAO's work in 2015 showed that the $82 \%$ of producers respecting the preharvest intervals, had a fairly high level of education. This is contrary to our case, where only $40 \%$ of producers have a secondary education level and $6 \%$ a higher education level, values very far from that obtained by the FAO (FAO, 2015).

Similar results were obtained in Brazil by (Römbke et al., 2007) in their study where they found that farmers do not understand pesticide label information (Römbke et al., 2007). With the same idea, Viviana Waichman, Evaldice eve and Nailson Nina indicated in their study (Waichman et al., 2006) that farmers do not read the instructions on the labels of plant protection products, claiming that the font is very small but also that these instructions are long enough to read and remember. This can also justify the fact that only 9\% of the producers surveyed in Foumbot take into consideration the instructions mentioned on the product labels before use.

\section{Knowledge of impact of pesticides on health}

Only $9 \%$ of farmers mentioned that the products used may be present in the fruit and therefore harm the health of end consumers. This lack of knowledge on the socio-environmental impacts linked to the mismanagement of phytosanitary products, justified by the high rate of the uninformed population (81\%), is directly results in non-wearing the personal protective equipment (PPE) in the field by all of the producers when handling plant protection products. On the other hand, farmers take no specific environmental protection measure after using phytosanitary products: empty packages are usually left on the spot of use, in the different sprayed plantations. In some cases, farmers use them for domestic purposes. They are therefore cleaned and used as a drinking water bottle (most encountered case). In addition, these empty packages have essential functions for traders, especially for those with a volume of one liter. They are most often used as measuring containers when selling red palm oil, white palm wine and traditional maize beverage. Empty packaging reused after treatment or discarded in nature constitutes a source of serious dangers for man and his environment. Indeed, (Gomgnimbou et al., 2009) have shown that the use of empty cans of pesticides, after or without washing, for the packaging of consumable goods such as water, palm wine and red oil is a source of health dangers for the populations. On the other hand, abandoned in nature, they contribute to the pollution of the soil, water by runoff and infiltration and then of the air by evaporation. (Lehmann, 2016) meanwhile underlines the pollution of certain waterways by pesticide residues in market garden areas. Certain water reservoirs constituting the supply points for wild animals, but also being able to serve as fish farming, it follows an indirect transfer of pesticide residues to humans through the food chain as 
approved. (Agbohessi et al., 2012) in Benin through tilapia under similar conditions.

\section{Pesticide residues in tomato samples}

Among the 17 pesticides tested in the 15 tomato samples, only 03 pesticides were detected and quantified by GCMS, all of which were insecticides. The most distributed pesticide was lambda-cyhalothrin (found in $100 \%$ of samples), followed by cypermethrin (86.66\%) and acetamiprid (66.66\%) (Table 3). In previous work (Galani et al., 2018), only 44 (54.3\%) of the 81 compounds were found in the samples of the same food items originating from the western highlands of Cameroon. Herbicides represented 16.2\%, 30.9\% were fungicides, and insecticides were 39.7\%. (Galani et al., 2020).in the study of Guimou et al.,2008 on Dietary exposure to pesticide residues in Yaoundé: The Cameroonian total diet study, Of the 46 pesticides analyzed only nine pesticides were detected: Atrazine, chlorothalonil, cypermethrin, deltamethrin, endosulfan, malathion, pirimiphos-methyl, DTC and chlordecone. As a present study, food samples contained little pesticides compounds, and only insecticides were found. Of the three quantified pesticides, all samples were above the MRL for lambda-cyhalothrin, 92.30\% for cypermethrin, and $66.66 \%$ for acetamiprid (Table 3). This indicates the high use of products made from lambda-cyhalothrin, cypermethrin and acetamiprid by the producers of Foumbot. The high percentage of residue content above the MRL this can be justified by lack of good agricultural practices (GAP) leading to inappropriate application of pesticide by farmers because of insufficiency of training and deficiency of assistance from agricultural extension agents (Manu et al., 2014; Tarla et al., 2015). hence the necessity of actions to be taken by regulatory authorities to regulate usage of agrochemicals in the country (Galani et al., 2018; Sonchieu et al., 2013; Tarla et al., 2014). Yet studies by Doumbia (2009), (Ahouangninou et al.,2011), (Belhadi et al., 2016) and (Son et al., 2017) have shown that the intensification of treatments and non-compliance with the recommended doses contribute to the serious destruction of the environment but also increase the amount of pesticide residues in tomato fruits with harmful effects on the health of end consumers.

Table 3: Pesticide residue contents of tomato samples from Foumbot, Western highland Cameroon.

\begin{tabular}{|c|c|c|c|c|c|c|c|c|}
\hline Analytes & $\begin{array}{c}\begin{array}{c}\text { Numb } \\
\text { er of } \\
\text { positiv } \\
\text { es } \\
\text { sampl } \\
\text { es }\end{array} \\
\end{array}$ & $\begin{array}{c}\begin{array}{c}\text { Percent } \\
\text { of } \\
\text { positive } \\
\text { s } \\
\text { samples } \\
(\%)\end{array} \\
\end{array}$ & $\begin{array}{c}\text { Lowe } \\
\text { st } \\
\text { conte } \\
\text { nt } \\
(\mathbf{m g} / \mathbf{k} \\
\text { g) } \\
\end{array}$ & $\begin{array}{c}\text { Highe } \\
\text { st } \\
\text { conte } \\
\text { nt } \\
(\mathbf{m g} / \mathbf{k} \\
\text { g) } \\
\end{array}$ & $\begin{array}{l}\text { Median } \\
\text { content } \\
\text { (mg/kg) }\end{array}$ & $\begin{array}{c}\begin{array}{c}\text { Number } \\
\text { of } \\
\text { samples }\end{array} \\
\text { MRL }\end{array}$ & $\begin{array}{c}\text { Means } \\
\text { conten } \\
t \\
\mathrm{mg} / \mathrm{Kg}\end{array}$ & 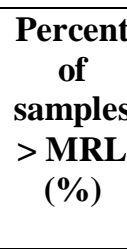 \\
\hline
\end{tabular}




\begin{tabular}{|c|c|c|c|c|c|c|c|c|}
\hline $\begin{array}{c}\text { Cypermeth } \\
\text { rin }\end{array}$ & 13 & 86.66 & 0.35 & 1.34 & 0,81 & 12 & 0,70 & 92.30 \\
\hline $\begin{array}{c}\text { Lambda- } \\
\text { cyhalothrin }\end{array}$ & 15 & 100.00 & 0.32 & 1.84 & 1,00 & 15 & 1,09 & 100.00 \\
\hline $\begin{array}{c}\text { Acetamipri } \\
\text { d }\end{array}$ & 11 & 66.66 & 0.34 & 1.20 & 0,51 & 1 & 0,49 & 9.09 \\
\hline
\end{tabular}

\section{Conclusion and recommendation}

In summary, the present study focuses on assessing phytosanitary practices of tomato producers in Foumbot, Western Highlands-Cameroon and evaluation of 17 pesticides residues in tomatoes. Our methodological approach is consistent with field investigations, statistical and laboratory analysis and results, interpretation and discussion. Statistical analysis of data obtained from the survey of 100 tomato producers has shown that farmers who grow tomatoes in the Foumbot Sub-division do not follow appropriate plant protection application procedures as indicated by the manufacturers and the Cameroon Phytosanitary Law. Moreover, laboratory analysis of some sample species has shown that all the samples were contaminated by 03 actives ingredients all containing lambda-cyhalothrin, cypermethrin (86.66\%) and acetamiprid 66.66\%). Residues of 03 pesticides (cypermethrin, lambdacyhalothrin and acetamiprid) were quantified in the samples, lambdacyhalothrin showing the highest level of contamination. The improvement of phytosanitary practices in Foumbot, Western Highlands requires training and extensive monitoring of tomato producers by the Cameroonian regulatory authorities. This study urges the Cameroonian regulatory authorities to train the farmers and monitor the application of pesticide, and realize analysis using HPLC and GC-ECD apparatus to detect more pesticides.

\section{Acknowledgement}

The authors are thankful to the Ministry of Agriculture and Rural Development (MINADER) particularly, the National Laboratory of Analysis and Diagnosis of Plant Products and Inputs $(L N A D)$. Moreover, all lecturer of department of agriculture especially Phytopathology and Agricultural Zoology Research Unit (UR-PHYZA) especially Prof YAOUBA Aoudou; Dr DJOMAHA ZANGUE Edwige Sidoine, Dr DZOKOU Victor Joly and Mrs. NKOUAM DJONKO Idriss.

\section{References:}

1. Abou Youssef, H.M., Farghaly, S.F., Singab, M., Ghoneim, Y.F. (2010). Resistance to lambda Cyhalothrin in laboratory strain of whitely Bemisia tabaci (genn.) and cross-resistance to several insecticides. American Eurasian journal agriculture and environmental sciences 7(6):693-696. 
2. Agbohessi, T.P., Toko, II., Kestemont, P. (2012). State of play of the contamination of aquatic ecosystems by organochlorine pesticides in the Beninois cotton basin. Cahiers Agricultures 21: 46-56

3. AGRESTE. (2016). Phytosanitary treatments in carrot, leafy cabbage, salad, tomato. Reunion, $n^{\circ} 12$.

4. Ahouangninou, C., Fayomi, B.E., Martin, T. (2011). Health and environmental risk assessment of the phytosanitary practices of market gardeners in the rural municipality of Tori-Bossito (South-Benin). Cahiers Agricultures 20 (3): 216-222. DOI: 10.1684 / agr.2011.0485.

5. Amiotte-Suchet, P. (2013). The biogeochemical cycle of Carbon. Chemical news 371-372: 25-29

6. Asongwe, G.A, Yerima, B.P.K., Tening, A.S. (2014). Vegetable Production and the Livelihood of Farmers in Bamenda Municipality, Cameroon. International Journal of Current Microbiology and Applied Sciences 3(12): 682-700

7. Aubertot, J.N., Barbier, J.M., Carpentier, A., Grill, J.J., Guichard, L., Lucas, P., et al. (2005). Pesticides, agriculture and the environment. Reduce the use of pesticides and their environmental impacts. Collective Scientific Expertise, INRA / CEMAGREF, 64 pges.

8. Badiane, M. (2004). Use of pesticides in the peri-urban market gardening system: annual variations and impacts on the health of populations. Doctoral thesis in Veterinary Medicine, Dakar, EISMV, $125 \mathrm{p}$.

9. Bazzi, L., Zougagh,M., Salghi, R., Hormatallah, A., Lemerhyeratte, A., Mihit, M., Chakir, A. (2012). Oriental Journal of Chemistry, 25 (2009) 461

10. Belhadi, A., Mehenni, M., Reguieg, L., Yahlef, H. (2016). Phytosanitary practices of greenhouse growers in three localities in the eastern Ziban region and their potential impact on human health and the environment. Revue Agriculture 1 (special issue): 9-16

11. Camara, M., Mbaye, A.A., Samba S.A.N., Gueye,T., Noba, K., Diao, S., Cilas, C. (2013). Study of the productivity and sensitivity of various varieties of tomatoes (lycopersicon esculentum mill) to yellowing and leaf curl virus in Senegal. Int. J. Biol. Chem. Sci. 7 (6): 2504-2512

12. Cissé, I., Fall, S.T., Badiane, M., Diop, Y., Diouf, A. (2006). Horticulture et usage des pesticides dans la region de Niaye au senegal, Document de travail, Ecocité n8.ISRA/LNERV, EISMV, LAG/ Faculte de medecine pharmacie/UCAD. Disponible sur www.ecocite.org; $14 p$

13. Chougourou, D.C., Agbaka, A., Adjakpa, J.B., Koutchika, R.E., Kponhinto, U.G., Adjalian, E.J.N. (2012). Preliminary inventory of the entomofauna of tomato fields (lycopersicon esculentum mill) in the 
commune of Djakotomey in Benin. Int. J. Biol. Chem. Sci. 6 (4): 17981804

14. Doumbia, M., Kwadjo, K.E. (2009). Pesticide use and management practices by market gardeners in the Ivory Coast: case of the city of Abidjan and two of its suburbs (Dabou and Anyama). Journal of Applied Biosciences 18: 992-1002

15. Ekengoue, C.M., Lele, R.F., Dongmo, A.K. (2018). Influence of artisanal sand mining on the health and safety of artisans and the environment: case of the Nkol'Ossananga quarry, Central Cameroon Region. European Scientific Journal (4): 246-268

16. FAO (Food and Agriculture Organization of the United Nations). Summarized data from 1970-1990s estimates of Asia and Latin America farm households. Available at: Accessed: July 2015

17. FAO. (2018). Diagnostic study of postharvest loss reduction of three cassava crops | Tomato | Potato Synthesis Report

18. FAOSTAT. (2018). Statistics Division of the Food and Agriculture Organization of the United Nations

19. Fontem, D.A. (2003). Quantitative effects of early and late blights on tomato yields in Cameroon. Tropicultura 21(1): 3641

20. Galani, J.H.Y., Houbraken, M., Wumbei, A., Djeugap, F.J., Fotio, D., Yung Yung Gong., \& Spanoghe, P. (2020). Monitoring and dietary risk assessment of 81 pesticide residues in 11 local agricultural products from the 3 largest cities of Cameroon. Food control 118.

21. Galani, J.H.Y., Houbraken, M., Wumbei, A., Djeugap, F.J., Fotio, D, \& Spanoghe, P. (2018). Evaluation of 99 pesticides residues in major agricultural products from the western highlands zone of Cameroon using QuEChERS method extraction and LC-MS/MS and GC-ECD analyses. Foods, 7 (11), 184-201.

22. Gimou, M.M., Charrondiere, U. R., Leblanc, J.-C., \& Pouillot, R. (2008).

Dietary exposure to pesticide residues in Yaoundé: The Cameroonian total diet study. Food Additives

Contaminants: Part A, 25(4), 458-471. https://doi.org/10.1080/ 02652030701567475.

23. Gnakine, O., Mouton, L., Avadogo, A., Martin, T., Sanon, A., Dabire, R.K et al. (2013). Biotype status and resistance to neonicotinoids and carbosulfan in Bermicia tabaci (Hemiptera: Aleyrodidae) in Burkina Faso,west africa. Internationnal of pest management 59(2): 95-102. DOI 10 1080/09670874.2013.771806

24. Gomgnimbou, A.P.K., Savadogo, P.W., Nianogo, A.J., MillogoRasolo-dimby, J. (2009). Use of chemical inputs in a tropical agrosystem: diagnosis of the risk of environmental pollution in the 
cotton region of eastern Burkina Faso. Biotechnology, Agronomy, Society and Environment 13 (4): 499-507

25. Gouda, A.I., Toko II., Salami, S.-D., Richert, M., Scippo, M.-L, Kestemont, P., Schiffers, B. (2018). Phytosanitary practices and level of exposure to pesticides of cotton producers in northern Benin. Cahier Agriculture 27: 65002

26. Ingenbleek, L., Jazet, E., Dzossa, A.D., Adebayo, S.B., Ogungbangbe, J., Dansou, S., Leblanc, J.C. (2017). Methodology design of the regional sub-saharan Africa total diet study in Benin, Cameroon, Maliand Nigeria. Food and Chemical Toxicology,109, 155-169.

27. Kanda,M., Djaneye-Boundjou, G., Wala, K., Gnandi, K., Batawila, K., Sanni, A., et al. (2013). Application of pesticides in market gardening in Togo. VertigO - The Electronic Journal for Environmental Sciences 13 (1): 1-17. DOI: 10.4000 / vertigo.13456.

28. Kenko, N.D.B., Asanga, B.F.P., Tchamadeu, N.N., \& Mpoame, M. (2017). Environmental and human healt hassessmentin relation to pesticide use by local farmers and the Cameroon development corporation (CDC), Fako division, South- West Cameroon. European Scientific Journal,13(21),454-473. https://doi.org/10. 19044/esj. 2017.v13n21p454

29. Kpan Kpan et al. (2019). Phytosanitary practices in peri-urban agriculture and contamination of foodstuffs by pesticides: the case of market gardeners in Port-Bouët (Abidjan). Journal of Animal \& Plant Sciences.

6847-6863.

https://doi.org/10.35759/JAnmPlSci.v41-1.11

30. Lehmann, E., Morgan Fargues, M., Congo, N., Konaté, Y., De Alencastro, L.F. (2016b). Pesticide application in gardening: assessment of resulting impact on water resources quality using grab sampled and pocis, case study of Loumbila lake, Burkina Faso. In: 9th European Conference on Pesticides and Relatd organic Micropolluants in the Environment (Santiago de Compostela). Accessed on October 2, 2020. Available at: https://www.researchgate.net/publication/317647132_PESTICIDE_A PPLICATION_IN_GARDENING_ASSESSMENT_OF_RESULTIN G_IMPACT_ON_WATER_RESOURCES_QUALITY_USING_GR AB_SAMPLES_AND_POCIS_CASE_STUDY_OF_LOUMBILA_L AKE_BURKINA_FASO

31. Lehmann, E., Oltramare, C., Nfon, D.J.J., Konaté, Y., De Alencastro, L.F., (2016a). Assessment of occupational exposure to pesticides with multi-class pesticide redidues analysis in human hairs using a modified QuECHERS extraction method, case study of gardening areas in Burkina Faso. In: Annual Meeting of the International Association of 
Forensic Toxiocologists (TIAFT), Brisbane, Australia. Accessed on September 12, $2020 . \quad$ Available at: https://infoscience.epfl.ch/record/221328?ln=en

32. Mahugija, J.A.M., Khamis, F.A., Lugwisha, E.H.J. (2017). Determination of levels of organochlorine, organophosphorus, and pyrethroid pesticide residues in vegetables from markets in Dar es Salaam by GC-MS. Int J Anal Chem [Internet]. 2017; 2017:1-9. Available: file://C:/Users/Admin/Downloads /4676724.pdf

33. Manfo, F.P., harthe, C., Akono, E., Dechaud, H., Nkouatchoua, A.T., Zabot, M.T., Pugeat, M \& Fewou, P.M. (2019). biphenol a differentially affect male reproduction function biomarker in a reference population and agropeticide ue in djuitita, Cameroun., Toxicology and Industrial Health 35(4), 324-335,2019 http:// doi.org/10.1177/0748233719838437

34. Manu, P., Ankrah, N., Proverbs, D., and Suresh, S. (2014). The health and safety impact of construction project features. Engineering, Construction and Architectural Management, 21 (1). pp. 65-93. http://dx.doi.org/10.1108/ECAM-07-2012-0070

35. MINADER / DESA / AGRI-STAT. (2012). Agricultural sector statistics yearbook: Campaign 2009 \& 2010 Yaoundé. Cameroon. Surveys and Statistics Unit 123pp.

36. MINADER.

Décision N01326/16/D/MINADER/SG/DRCQ/SDRP/SRP portant interdiction de l'importation et de l'homologation des formulations de pesticide à base de métalaxyl au Cameroun. Ministère de l'Agriculture et du Développement Rural (MINADER)

37. Multigner, L. (2005). Retarded effects of pesticides on human health. Environments., Risks and Health 4 (3): 187-194

38. Payne, J.R \& Phillips, C.R. (1985). Photochemistry of petroleum in water. Environ. Sci. Technol. 19 : 569-579.

39. Petrigh, C. (2019). Le conflit Anglophone au Cameroun un dialogue an partenaire. Note de ifri, ifri octobre 2019. Accessed on October 15, 2020. Available at: https://www.ifri.org/fr/publications/notes-delifri/conflit-anglophone-cameroun-un-dialogue-partenaires

40. Römbke, J., Waichman, A.V., Gracias, V.B.M. (2007). Risk assessment of pesticides for soil of the central amazon, Brazil: comparing outcomes with temperate and tropical data. Integrated Environmental Assessment Management, 4 (1): 94-104

41. Son, D., Somda, I., Legreve, A., Schiffers, B. (2017). Phytosanitary practices of tomato growers in Burkina Faso and risks to health and the environment. Cahiers Agricultures 26 : 25005. DOI : 10.1051 / cagri / 2017010. 
42. Sonchieu, J., Benoit, N, M., Bosco, T. J., Srivastava, A.K., \& Srivastava, L.P. (2010). Survey of pesticide residues in maize, cowpea and millet from northern Cameroon: Part I. Food https:// doi.org/10.4236/as.2019.108079.

43. Sonchieu, J., Ngassoum, M.B., Tchatchueng, J.B., Srivastava, A.K., \& Srivastava, L.P. (2013). Contamination of cowpea and by-products by organophosphorous pesticide residues in Ngaoundere markets: Dietary risk estimation and degradation study. African Journal of Food Science,7(5),92-102. https://doi.org/10.5897/AJFS2013. 1013.

44. Sonchieu, J., Fointama, E., Akono, N.E., Serri, B. (2019). Farmers' Knowledge, Attitude and Practices on Pesticide Safety: A Case Study of Vegetable Farmers in Mount-Bamboutos Agricultural Area, Cameroon. Agricultural Sciences, 10(08), 1039-1055. https://doi.org/10.4236/as.2019.108079

45. Stephens, R.D., Hatayama, H.K., Holden, A.M., Brown, B.A., \& Raymond, G.E. (1981). A Study of the Fate of Selected Toxic Materials in Waste Oils Used for Dust Palliation on Logging Roads in the Plumas National Forest, submitted in Partial Fulfillment of US Department of Agriculture (Forest Service), Contract No. 53-91S886132 for the Hazardous Materials Laboratory Section, California Department of Health Services, Berkeley, CA.

46. Steven, J. (2007). Determination of pesticide residues in foods by acetonitrile extraction and partitionning with magnesium sulfate: collaborative sulfate: collaborative study.in journal of AOAC international 90(2):485

47. Tandi, TE., Wook, C.J., Shendeh, T.T., ko, A.E., Afoh, C.O. (2014). Small-Scale Tomato Cultivators' Perception on Pesticides Usage and Practices in Buea Cameroon, Health, 2014, (6), 2945-2958 2014, http://dx.doi.org/10.4236/ health. 2014. 621333

48. Tarla, D.N., Meutchieye, F., Assako, V.A., Fontem, D.A., Kome, J.J.A. (2013). Exposure of market gardeners during pesticide application in the western highlands of Cameroon. Scholarly Journal of Agricultural Science 3 (5): 172-177

49. Tarla, D.N., Tchamba, N.M., Baleguel, N.P., Fontem, D.A., Baleguel, P.D., \& Hans, D. (2014). Inventory of obsolete pesticide stock piles in Cameroon. Scholarly Journal of Agricultural Science, 4 (1), 43-50.

50. Tarla, D.N. (2015). Plight of Pesticide Applicators in Cameroon: Case of Tomato (Lycopersicon esculentum Mill.) Farmers in Foumbot. Journal of Agriculture and Environmental Sciences 4 (2) 87-98

51. Tayoh, L.N., Kiyo, M.L.I., \& Nkemnyi, M.F. (2016). Chemical fertilizer application and farmer's perception on food safety in Buea, Cameroon. Agricultural Science Research Journal, 6 (12), 287-295. 
52. Waichman, A.V., Eve, E., Nina da Celso N. (2006). Do farmers understand the information displayed on pesticide product labels? a key question to reduce pesticides exposure and risk of poisoning in the Brazilian Amazon. Crop protection 26: 576-583

53. Wognin, A.S., Ouffoue, S.K., Assemand, E.F., Tano, K., Koffi-Nevry, R. (2013). Perception of health risks in market gardening in Abidjan, Côte d'Ivoire. International Journal of Biological and Chemical Sciences 7 (5): 1829-1827. DOI: 10.4314 / ijbcs. v7i5.4. 